\title{
INTELLIGENT CONTROL OF ELECTRICAL DRIVE SYSTEM USED FOR
} ELECTRIC VEHICLES

\author{
SILAGHI HELGA ${ }^{1}$, GAMCOVA MARIA ${ }^{2}$, SILAGHI ANDREI MARIUS ${ }^{3}$, \\ SPOIALĂ VIORICA ${ }^{1}$, SILAGHI ALEXANDRU MARIUS ${ }^{1}$, SPOIALĂ DRAGOȘ ${ }^{1}$ \\ ${ }^{1}$ University of Oradea, Romania, Department of Control Systems Engineering and Management, \\ Faculty of Electrical Engineering and Information Technology, University Street, 1, 410087 Oradea, Romania, \\ E-Mail: hsilaghi@uoradea.ro, vspoiala@uoradea.ro, masilaghi@uoradea.ro, dspoiala@uoradea.ro \\ ${ }^{2}$ Technical University of Kosice, Slovakia, Faculty of Electrical Engineering and Informatics, \\ E-Mail: maria.gamcova@tuke.sk \\ ${ }^{3}$ Polytechnica University of Timisoara, Romania, Faculty of Electronics and Telecommunications, \\ E-Mail: andrei.silaghi@student.upt.ro
}

\begin{abstract}
An electric vehicle (EV) uses an electric motor for traction and chemical batteries, superconductors, combustion cells and / or inertial masses as energy sources. To avoid problems regarding the accuracy of the mathematical model of the system, the use of artificial intelligence in electric drives is a viable alternative. Among other advantages of using artificial intelligence in the electric drive system, it can be emphasized that its application reduces the design time and leads to avoiding problems with the introduction of the mathematical model in the system control algorithm. This paper presents several case studies of electrical vehicles and some considerations about intelligent control of EVs. Finally some experimental results that compare classical control system with fuzzy logic control system for $E V$ are presented.
\end{abstract}

Keywords: electric vehicle, intelligent control, three-phase induction motor, fuzzy logic

\section{INTRODUCTION}

An electric vehicle (EV) uses an electric motor for traction and chemical batteries, superconductors, combustion cells and / or inertial masses as energy sources. The electric vehicle has many advantages over the internal combustion engine vehicle, for example: it operates silently, does not pollute, does not use fossil fuels and has a high efficiency. The operating principles are similar to those of the conventional internal combustion engine, but there are also some differences: the electric vehicle uses the battery as the primary energy source for the propulsion and the other fossil fuel (diesel, gasoline, gas), the classic vehicle uses the internal combustion engine and the electric vehicle uses the electric motor and, last but not least, the transmission of the two types of vehicles is different [1].

The "Heart" of Electric Vehicles (VE) and Hybrid Electric Vehicles (VHE) is the electric propulsion systems. These are composed of electric motors, electronic control systems (made with Digital Signal Processors - DSP - microcontrollers) and power converters [2]. For the propulsion of the electric vehicle, the electric motor converts electricity into mechanical energy, or, vice versa, in the regenerative braking process, generates electricity to charge the batteries.

For powering the electric motor with the necessary voltages and currents, the power converter is used. The electronic control system supplies control signals to the power converter on the grid / base [3-4].

\section{CASE STUDIES OF COMMERCIAL ELECTRIC VEHICLES}

In these case studies will be presented comparatively performance of modern electric vehicles since the 60 s, the so-called modern era of electric vehicles.

In the 60's the factors that have led to further research and development of electric vehicle are [1]:

- Increased air pollution due to increasing number of vehicles with internal combustion engines;

- U.S. Congress introduced new environmental taxes and recommended the use of electric vehicles to reduce pollution;

- Major car manufacturers began research on the production of electric vehicles (for example, General Motors - GM, Ford)

\subsection{Case study in the 60's}

\section{Electric Vehicles Electrovair I (1964) and Electrovair} II (1966) at GM

Uses a Chevy Corvair chassis and body.

Characteristics:

- $\quad$ three-phase induction motor $115 \mathrm{HP}, 13000 \mathrm{rpm}$;

- $\quad$ Ag-Zn Battery 512 V 680 Lbs (1 Pound=0,4536 $\mathrm{kg})$;

- DC-AC or SCR Inverter;

- $\quad$ maximum speed $80 \mathrm{mile} / \mathrm{h}(1 \mathrm{mile}=1,6093 \mathrm{~km})$;

- autonomy 40-80 miles;

- $\quad$ acceleration 0-60 miles/h in 15,6 sec; 
- Vehicle Weight 3400 Lbs.

Qualities: acceleration comparable to a vehicle with internal combustion engine Corvair

Drawbacks: the battery is expensive, heavy, has a short life cycle and long recharge time.

However, in 1960, the technology was not mature enough to produce widespread viable electric vehicles.

In the 70's the factors that have spurred further research in electric vehicle were:

- significant increase in gasoline prices;

- arab oil embargo of 1973 led to the need to find alternative energy sources;

- in 1975, the US Postal Service delivered for testing a number of 352 electric vehicles;

- in 1976, the U.S. Congress issued public law 94-413 on research of electric vehicles;

- Department of Energy (DOE) in the US standardized performances required of EVs.

\subsection{Case study in the 70's}

Electric Vehicle - uses a Chevy Chevette chassis and modified body.

System and features:

- D.C. motor with separate excitation, 34 HP, 2400 rpm;

- Ni-Zn battery 120 V 735 Lbs;

- Ni-Zn 14 V auxiliary battery;

- electric drive system using chopper;

- maximum speed $60 \mathrm{miles} / \mathrm{h}$;

- autonomy 60-80 miles;

- acceleration 0-55 miles/h in $27 \mathrm{sec}$.

This VE was used more as a test for Ni-Zn battery covering a distance of more than 35.000 miles.

\subsection{Case study in the 90's}

The factors behind the research in the field of electric vehicles were:

A. Technological development. Development of magnetic flywheel bearings used in energy storage systems. The emergence of new types of power semiconductors and the revolution of microprocessors have led to the emergence of new control methods and the design development of electronic power converters.

B. EV development directions in recent years. Intense activity at Toyota, GM, Ford and Chrysler, substantial input from other independent producers, new prototypes are better, intense activity in the field of hybrid vehicles.

\section{GM Impact 3}

- $\quad$ Based on the 1990 Impact model presented at the Los Angeles Auto Show;

- $\quad$ Three-phase induction motor, 137 HP, 12000 rpm;
- $\quad$ Battery 26 lead-acid $12 \mathrm{~V}$ units serial connected (312 V, 869 Lbs);

- $\quad$ DC-AC inverter drive with IGBT;

- Maximum speed 75 miles / h, 90 miles off the motorway;

- $\quad$ Acceleration 0-60 miles in 8,5 sec;

- Weight 2900 Lbs.

\section{Saturn EV1}

- EV commercially manufactured by GM;

- Launched in California and Arizona for a price of 30000\$;

- $\quad$ Three-phase induction motor;

- $\quad$ Battery lead-acid;

- DC-AC inverter drive with IGBT;

- Maximum speed 75 miles/h;

- Autonomy 90 miles off the city or 70 miles in the city;

- $\quad$ Acceleration 0-60 miles in 8,5 sec;

- Consumption of $30 \mathrm{kWh} / 100$ miles in the city or $25 \mathrm{kWh} / 100$ miles outside the city.

A comparison between autonomy, maximum speed, electric motor, battery and weight for different EVs is presented in Table 1 .

Table 1. Electric Vehicles

\begin{tabular}{|c|c|c|c|c|c|}
\hline & $\begin{array}{c}\text { GM } \\
\text { Impact }\end{array}$ & $\begin{array}{l}\text { Ford } \\
\text { Ecostar }\end{array}$ & \begin{tabular}{|c|} 
Chrysler \\
Epic \\
Van \\
\end{tabular} & $\begin{array}{c}\text { BMW } \\
\text { E2 }\end{array}$ & $\begin{array}{c}\text { Nissan } \\
\text { FEV }\end{array}$ \\
\hline $\begin{array}{c}\text { Autonomy } \\
\text { (miles) }\end{array}$ & 120 & 100 & 120 & 150 & 150 \\
\hline $\begin{array}{c}\text { Maximum } \\
\text { speed } \\
(\mathrm{miles} / \mathrm{h})\end{array}$ & 75 & 65 & 65 & 75 & 80 \\
\hline $\begin{array}{l}\text { Electric } \\
\text { motor }\end{array}$ & $\begin{array}{c}2 \mathrm{x} \\
50 \\
\text { HP. } \\
\text { a.c. }\end{array}$ & $\begin{array}{c}75 \mathrm{HP} \text {. } \\
\text { a.c. }\end{array}$ & $\begin{array}{c}65 \\
\text { HP. } \\
\text { d.c. }\end{array}$ & $\begin{array}{c}45 \mathrm{CP} . \\
\text { d.c. }\end{array}$ & $\begin{array}{r}2 \times 27 \\
\text { CP. a.c. }\end{array}$ \\
\hline Battery & $\begin{array}{c}\text { Lead } \\
- \\
\text { Acid }\end{array}$ & $\begin{array}{l}\text { Sodiu } \\
\text { m } \\
\text { sulphit } \\
\mathrm{e}\end{array}$ & $\begin{array}{c}\text { Nickel } \\
\text {-Iron }\end{array}$ & $\begin{array}{c}\text { Sodiu } \\
\mathrm{m} \\
\text { sulphit } \\
\mathrm{e}\end{array}$ & $\begin{array}{c}\text { Nickel- } \\
\text { Cadmiu } \\
\text { m }\end{array}$ \\
\hline $\begin{array}{l}\text { Weight } \\
\text { (Lbs) }\end{array}$ & 2200 & 3100 & 3200 & 2020 & 1980 \\
\hline
\end{tabular}

A brief comparison between Electric Vehicles EV and Internal Combustion Engines ICE is presented. Table 2 contents a comparison between the yiels of EV and ICE regarding different parameters [3], [10].

Table 2. Comparison of yield

\begin{tabular}{|l|c|l|c|}
\hline \multicolumn{1}{|c|}{ ICE } & $\begin{array}{c}\text { yield } \\
(\%)\end{array}$ & \multicolumn{1}{|c|}{ VE } & $\begin{array}{c}\text { yield } \\
(\%)\end{array}$ \\
\hline Refining oil & 90 & Oil refining & 97 \\
\hline $\begin{array}{l}\text { Pump } \\
\text { distribution }\end{array}$ & 99 & $\begin{array}{l}\text { Generating } \\
\text { electricity }\end{array}$ & 40 \\
\hline Motor & 22 & $\begin{array}{l}\text { Transmission to } \\
\text { engine wheels }\end{array}$ & 92 \\
\hline $\begin{array}{l}\text { Transmission / } \\
\text { ax }\end{array}$ & 98 & Battery charging & 90 \\
\hline $\begin{array}{l}\text { Total yield } \\
\text { (Crude oil } \\
\text { extraction - } \\
\text { engine wheels) }\end{array}$ & 19 & $\begin{array}{l}\text { Total yield } \\
\text { (refining oil- } \\
\text { engine wheels) }\end{array}$ & 20 \\
\hline
\end{tabular}




\section{Comparison of pollution}

In case of $100 \%$ replacement of classical vehicles with $\mathrm{EV}$, the following are obtained:

- Carbon dioxide in the air would be halved;

- Nitrogen oxide would be reduced;

- Sulfur dioxide would increase slightly;

- Oil consumption would drop;

- Sonic pollution would be reduced.

In conclusion, the electric vehicle would considerably reduce the main sources of environmental pollution.

\section{Comparison of capital and operational costs}

- Initially, total EV costs would be higher than those of classic vehicles. However, over time, with the increase in sales volumes, it is expected to decrease the capital costs of EV. The main cause of the EV price increase is the battery and the control system.

- The total cost of a lifecycle of an EV is superior to that of the classic vehicle.

- Electric vehicles are becoming more and more reliable and thus require less maintenance [11].

\section{INTTELLIGENT CONTROL OF DRIVE SYSTEM FOR EV}

Using intelligent control does not require the mathematical models of the controlled system. Among other advantages of using artificial intelligence in the electric drive system, it can be emphasized that its application reduces the design time and leads to avoiding problems with the introduction of the mathematical model in the system control algorithm [5].

The main advantages that arise from the application of artificial intelligence: the design does not require the mathematical model of the set system; it can be designed based on linguistic information available from industry experts or using accumulation methods or other techniques; It may take less time than conventional controllers; Can be designed based on system response even in the absence of expert knowledge; Can be designed using linguistic information combined with system response; It can be relatively easily transformed into an adaptive control by including a new input variable that can become available at a time; Can provide control solutions when conventional methods can not. Intelligent control may have increased immunity to noise and does not increase the total cost of the system, especially for the minimum configuration and it is easy to modify and expand [6], [7].

Classical control techniques are based on the mathematical models of the system (electric motor, drive systems, electric vehicle), but in reality it is very nonlinear. By establishing a linear model of the system, many approximations will result.

To avoid problems regarding the accuracy of the mathematical model of the system, the use of artificial intelligence in electric drives is a viable alternative, being taken into account by more and more manufacturers of electric drive systems [12]. Many of the publications on the application of artificial intelligence in electric drives relate more often to fuzzy logic applications for controlling the position of the electric motor and, more rarely, to neural network applications [9].

Direct torque control for an asynchronous machine with PWM inverter basic structure is presented in Figure 1 [3], [8]. For position or speed control, this adjusting mode is proper, conducting to stabile adjustment until aproximatively 0,1 rotations/hour.

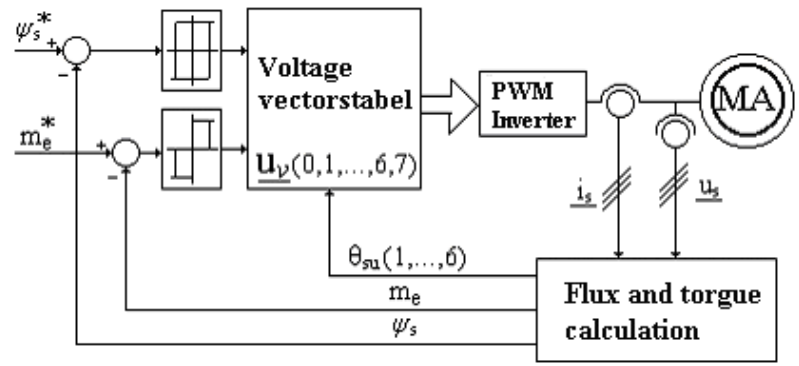

Figure 1. Direct torque control for an asynchronous machine with PWM inverter

In order to obtain a torque and flux response much faster, it is used the method that includes the fuzzy logic for optimal selection of the voltage vectors to be applied to the induction motor terminals via the voltage inverter.

A fuzzy logic system of the Mamdani type was used and the basic rules system for the selection of stator voltage vectors was determined. The inputs of this fuzzy system are: the stator flux errors $\varepsilon_{\Psi}$ and the electromagnetic torque $\mathrm{e}_{\mathrm{m}}$ and the position $\Theta_{\Psi_{\mathrm{s}}}$ of the spatial stator beam of the stator flux relative to the fixed stator reference system $\alpha-\beta$. The exits of the fuzzy logic system are those of the inverter valve states, represented by the order $v(0$, $1,2, \ldots, 7)$ of the voltage vector to be applied to the induction motor.

The purpose of using the fuzzy logic control in this case is to increase the performance of the drive system (for example, a much faster dynamic response of torque and stator flux). During the startup process, the inverter valve states must be selected, leading to the highest increase of the stator flux phaser module, because the torque cannot increase very quickly during this very short time. Then, when the flux error decreases, those states of the inverter valves that lead to the fastest increase of the electromagnetic torque must be selected. 
We made a selection of voltage vector based on fuzzy rules. Each rule (under the basic rules) can be described by the input variables $\left(\varepsilon_{\Psi}, \varepsilon_{\mathrm{m}}, \Theta_{\Psi_{\mathrm{s}}}\right)$ and the control variable represented by the switching state $v$.

The simplest procedure is to obtain the rules from physical considerations using the vectorial diagrams showing the relation between the position and the amplitude of the spatial phase of the stator flux according to the stator voltage vector of Figure 2:

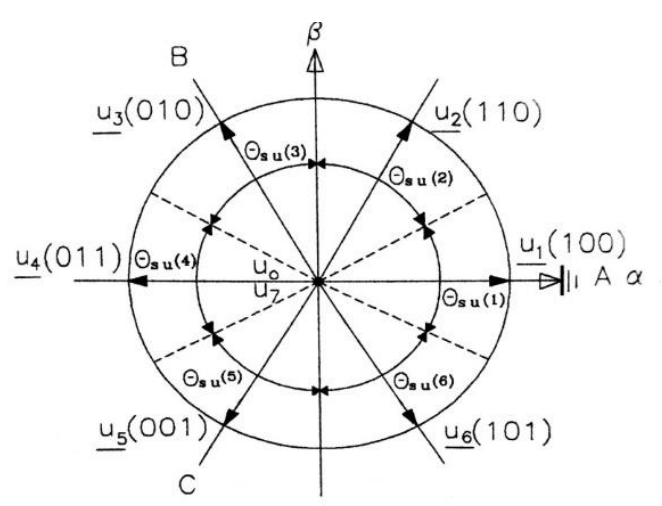

Figure 2. Stator voltage vector

It can be seen from the figure that, for example, the vector $\mathrm{u}_{1}$ which lies along the axis $\alpha$ of the stator reference system, corresponds to the state $(1,0,0)$ of the inverter valves.

The numbers in the above-mentioned spatial stator space relation (1) represent the control variables (blocking or conduction of the inverter valves) $(\mathrm{SA}=1, \mathrm{SB}=0, \mathrm{SC}=0)$.

Some fuzzy control rules can be determined, starting from some physical considerations. Thus, the spatial phasor of the stator flux can be at one point in one of the six sectors $\left(60^{\circ}\right.$ each $)$, but also at the overlapping limit of these regions.

Each sector of $60^{\circ}$ will be defined by the start and end angles relative to the stator reference system in the trigonometric sense and will represent the position $\Theta_{\Psi_{S}}$ of the spatial phaser of the stator flux with respect to the axis $\alpha$ of the stator reference system.

For each sector, there are 15 rules, because it was assumed that for the flux error are three fuzzy sets and for the torque error there are five fuzzy sets. In particular, the stator flow error can be positive (P), zero (ZE) or negative (N) corresponding to three sets of fuzzy overlapping (fuzzy set $\mathrm{P}$, fuzzy set $\mathrm{ZE}$ and fuzzy set $\mathrm{N}$ ). The electromagnetic torque error can be large and positive (PL), small and positive (PS), zero (ZE) . These choices were made in order to have torque variations as small as possible, the universe of variance of torque error being divided into five fuzzy sets of overlapping.

The position of the spatial phaser of the stator flux towards the fixed stator system is determined by knowing its components $\left(\Psi_{\mathrm{s} \alpha}, \Psi_{\mathrm{s} \beta}\right)$, under $\theta_{\Psi_{\mathrm{s}}}=\operatorname{arctg}\left(\Psi_{\mathrm{s} \alpha}{ }^{\prime}\right.$ $\Psi_{\mathrm{s} \beta}$ ).

There have been considered 12 sectors, the universe of variation of this angle being divided into 12 fuzzy sets (S1, S2, .., S12) and the corresponding membership functions are shown in Figure 3.
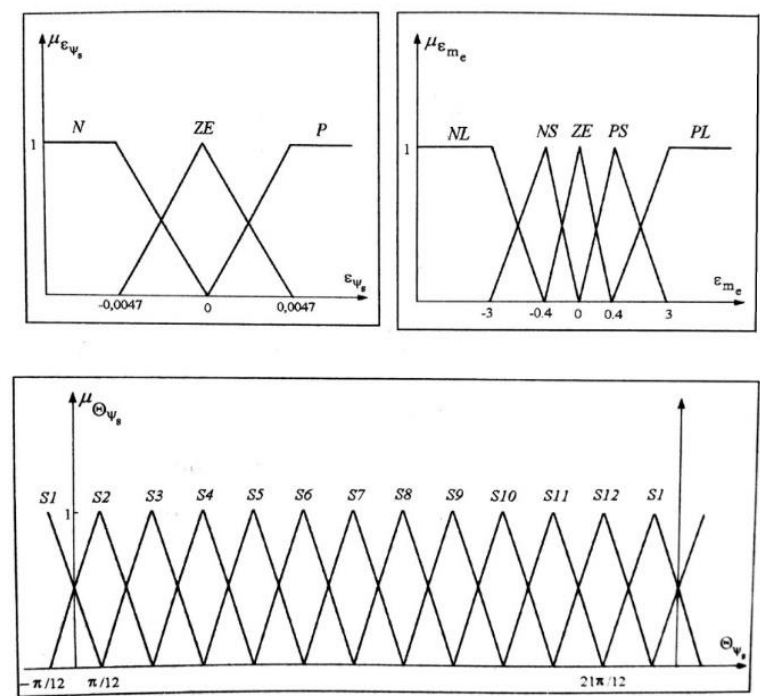

Figure 3. Membership features for flux error, torque error and the stator flux position

Taking into account that there are 12 sectors, the total number of rules is 180 . For example, the top three rules are:

Rule 1: If ( $\varepsilon_{\Psi}$ is $\mathrm{P}$ and $\varepsilon_{\mathrm{m}}$ is PL and $\Theta_{\Psi \mathrm{S}}$ is $\left.\mathrm{S} 1\right)$ Then ( $v$ is 1$)$.

Rule 2: If ( $\varepsilon_{\Psi}$ is $\mathrm{P}$ and $\varepsilon_{\mathrm{m}}$ is PS and $\Theta_{\Psi_{\mathrm{S}}}$ is S2) Then ( $v$ is 1$)$.

Rule 3: If ( $\varepsilon_{\Psi}$ is $\mathrm{P}$ and $\varepsilon_{\mathrm{m}}$ is $\mathrm{ZE}$ and $\Theta_{\Psi_{\mathrm{S}}}$ is $\mathrm{S} 3$ ) Then ( $v$ is 0 ).

These S1, S2 and S3 are so-called fuzzy labels (for example, $\mathrm{S} 1$ is the label for the stator flow position in sector 1, S2 is the fuzzy label for all stator flow positions in sector 2, etc.). For the stator flow position, 12 labels have been defined.

In this case, the outputs are numerical variables (inverter valve states $n=0,1,2, \ldots, 7$ ), using the maximum criterion for defuzzification - the fuzzy decision making engine of the order execution. The maximum criterion leads to a point where the control mode selection distribution reaches its maximum value. In this way, the output variable (command) is used as the fuzzy output variable having the highest degree of belonging.

\section{EXPERIMENTAL RESULTS}

For implementation, a Texas Instruments TMS320C32 floating-point digital signal processor control system was used. The tests were performed on a three-phase 
induction motor of $2.2 \mathrm{~kW}, 220 \mathrm{~V}, 60 \mathrm{~Hz}$ with $\mathrm{p}=2$ (pairs of poles) and the short-circuited rotor.

The reference electromagnetic torque is $12 \mathrm{Nm}$ (nominal torque) and the amplitude of the reference stator current is $0.82 \mathrm{~Wb}$ (nominal stator flux). The voltage of the intermediate circuit is $\mathrm{U}_{\mathrm{CC}}=225 \mathrm{~V}$, and the constant value was used for stator resistance is $R_{s}=0,435 \Omega$, so it is not necessary to use a new fuzzy estimator to determine it. The dynamic response of the electromagnetic torque for the classical control system is shown in Figure 4 and for the fuzzy logic system in Figure 5. Also, the stator flux response is shown in Figure 6 and Figure 7 for the two control systems.

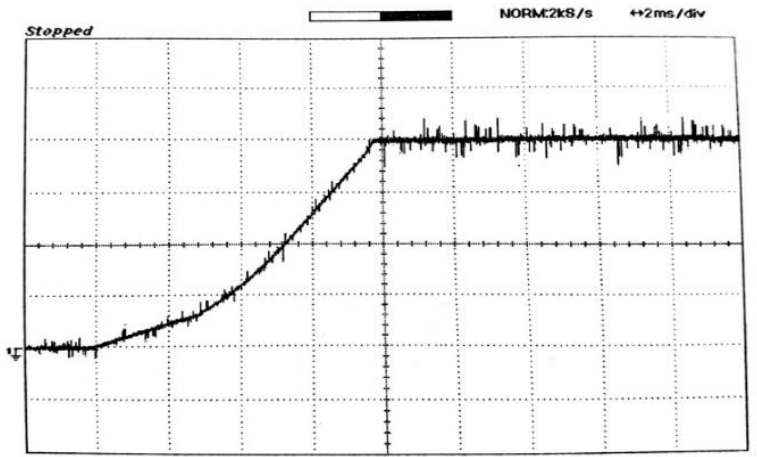

Figure 4. Conventional control system - Dynamic response electromagnetic torque at start (3 Nm/div; $2 \mathrm{~ms} / \mathrm{div})$

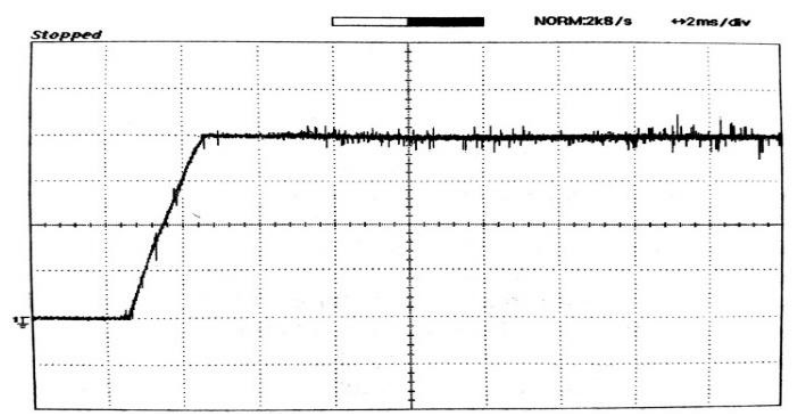

Figure 5. Fuzzy control system - Dynamic response electromagnetic torque at start $(3 \mathrm{Nm} / \mathrm{div} ; 2 \mathrm{~ms} / \mathrm{div})$

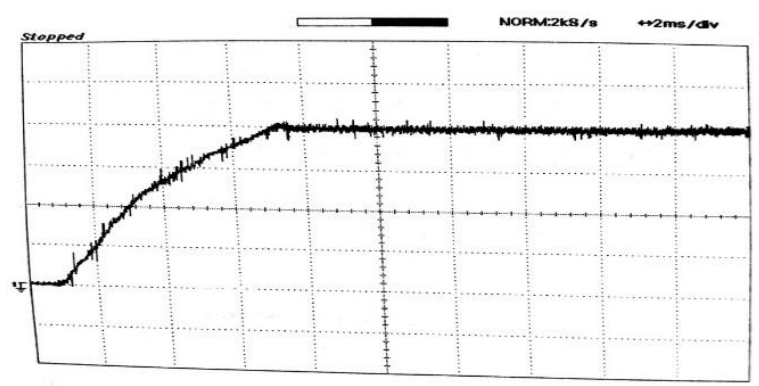

Figure 6. Conventional control system - Dynamic response of the stator flux at startup $(0.205 \mathrm{~Wb} / \mathrm{div} ; 2 \mathrm{~ms} / \mathrm{div})$

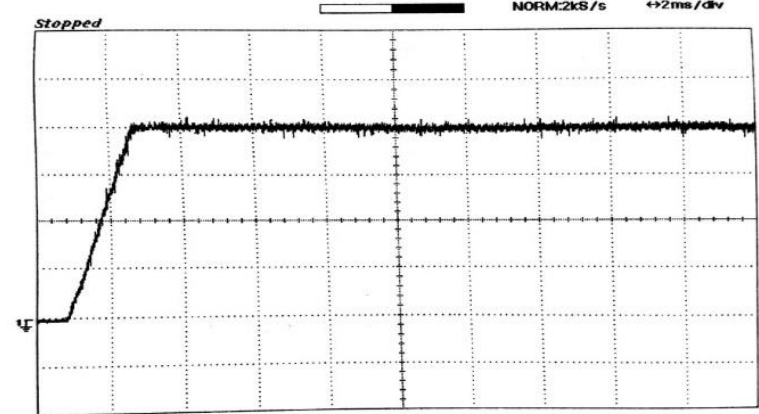

Figure 7. Fuzzy control system-Dynamic response of the stator flux at startup. $(0.205 \mathrm{~Wb} / \mathrm{div} ; 2 \mathrm{~ms} / \mathrm{div})$

As expected, the dynamic response of the fuzzy system is much better than the conventional system. In the case of the fuzzy logic system, the initial flow error is very high, the system selecting the voltage vectors for the purpose of rapidly increasing the stator flux. Changing the electromagnetic torque in this time is very small; when the flow error becomes low, the fuzzy system selects the voltage vectors needed for the rapid increase of the electromagnetic torque.

Figure 8 and Figure 9 show the electromagnetic torque response for the two cases (Conventional Control System, Fuzzy Control System) at the Load Torque Step $(12 \mathrm{Nm}$ to $6 \mathrm{Nm}$ ) respectively. As before, the fuzzy system has a faster response.

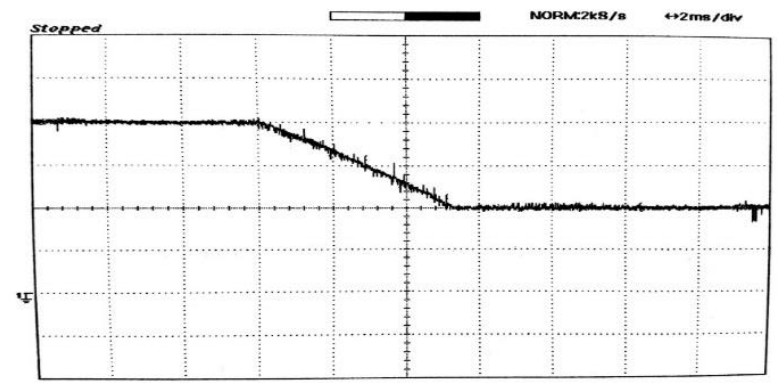

Figure 8. Conventional control system - Dynamic torque response to torque shock, discharge from $12 \mathrm{Nm}$ to $6 \mathrm{Nm}$ (3 Nm/div, 2ms/div)

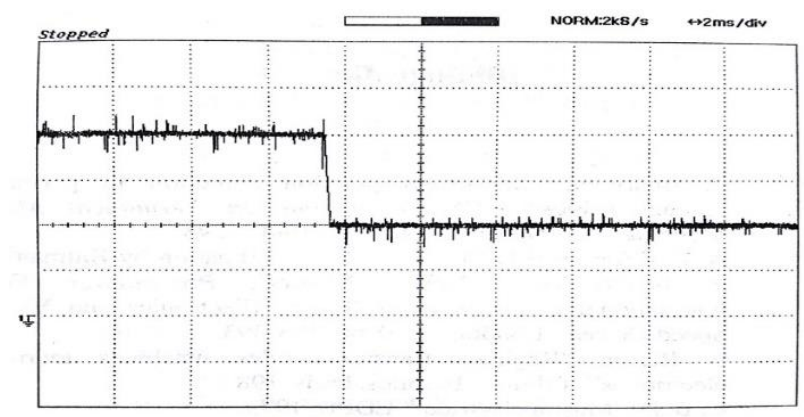

Figure 9. Conventional control system-Dynamic torque response to torque shock, discharge from $12 \mathrm{Nm}$ to $6 \mathrm{Nm}(3 \mathrm{Nm} / \mathrm{div}, 2 \mathrm{~ms} / \mathrm{div})$

In all the figures with the experimental results above, it can be observed that in a stabilized regime the response of the two systems is similar. This was made because, in 
the case of classical regulation, as the response speed increases, oscillations of the stabilized system may occur as a result of the increase of the amplification coefficient.

Considering the experimental results presented, it can be said that artificial intelligence also has a great potential for electric drives, and an increasing development of applications using fuzzy logic is expected.

\section{CONCLUSIONS}

This paper presents several case studies of electrical vehicles and some considerations about intelligent control of EVs.

EV would lead to the emergence of new jobs for electrician engineers in areas such as: design and development of electrical systems of an EV (power converters, motors, control design); power generators; EV infrastructure - deployment of load stations.

There are a few impediments to the large-scale introduction of EV: the limits of autonomy given by the capacity of the source (accumulators); use of numerous transducers, reducing system reliability and scope; capital costs of EV - low initial EV output leads to higher prices; EV infrastructure.

Using intelligent control does not require the mathematical models of the controlled system. Among other advantages of using artificial intelligence in the electric drive system, it can be emphasized that its application reduces the design time and leads to avoiding problems with the introduction of the mathematical model in the system control algorithm.

The purpose of using the fuzzy logic system in this case is to increase the performance of the drive system (for example, a much faster dynamic response of torque and stator flux). For this purpose, during the startup process, the inverter valve states must be selected, leading to the highest increase in the stator flux phasing module, since torque can not increase very quickly during this very short time. Then, when the flow error decreases, those states of the inverter valves that lead to the fastest increase of the electromagnetic torque must be selected.

As expected, the dynamic response of the fuzzy system is much better than the conventional system. In the case of the fuzzy logic system, the initial flow error is very high, the system selecting the voltage vectors for the purpose of rapidly increasing the stator flux. Changing the electromagnetic torque in this time is very small; when the flow error becomes low, the fuzzy system selects the voltage vectors needed for the rapid increase of the electromagnetic torque.
Considering the experimental results presented, it can be said that artificial intelligence also has a great potential for electric drives, and an increasing development of applications using fuzzy logic is envisaged.

\section{REFERENCES}

[1] D.O. Kisck, V. Navrapescu, Sisteme de propulsie pentru vehicule electrice, Editura Electra, 2017.

[2] See Loeb, A.P., Steam versus Electric versus Internal Combustion: Choosing the Vehicle Technology at the Start of the Automotive Age, Transportation Research Record, Journal of the Transportation Research Board of the National Academies, 1985.

[3] H. Andrei, F. Spinei, U. Rohde, M.A. Silaghi, H. Silaghi, Evaluation of Hilbert Space Techniques and Lagrange's Method for the Analysis of Dissipated Power in DC Circuits, European Conference on Circuit Theory and Design, ECCTD'09, 2009, Antalya, Turkey, IEEE Catalog Number: CFP09ECC-CDR, ISBN: 978-1-4244-3896-9, pp. 862-868.

[4] L.M. Matica, H. Oros, Speed Computation in Movement followed by Accurate Positioning, International Journal of Computers Communications \& Control, 12(1):76-89, 2017.

[5] A. Bara, Sisteme fuzzy - Aplicaţii la conducerea proceselor, Editura UT Press, Cluj - Napoca, 2001

[6] D.S. Bernstein, Rules Rule - Real Time Engineering, IEEE Control Systems Magazine, vol. 31, no. 3, pp. 6-7. 2011.

[7] J.Y. Fiset, Human-Machine Interface Design for Process Control Applications, ISA Press, USA, 2008.

[8] V. Spoială, H. Silaghi, Acţionări electrice speciale, Editura Universităţii din Oradea, 2010.

[9] A. Bara, S. Dale, C. Rusu, H. Silaghi, DC Electrical Drive Control with Fuzzy Systems, Proceedings of the 13th International Conference on Engineering of Modern Electric Systems, ICEMES 2015, Oradea, Romania, June 11-12, ISBN 978-1-4799-7651-5, pp. 207-210, 2015.

[10] S.V. Ciceo, H. Nagy, M. Ruba, C. Martis, H. Hedesiu, Real-Time Virtual Test-Banch for Electrical Vehicle Propulsion System, ACTA ELECTROTEHNICA, vol.57, nr.3-4, Editura Mediamira, Cluj-Napoca, 2016.

[11] A.M. Silaghi, De Sabata A., Alexa F., Buta A., Baderca S., Measurement of Radiated Immunity in the Automotive industry: Key concepts, Proceedings of 12th IEEE International Symposium on Electronics and Telecommunications (ISETC'16), Timisoara, 2016.

[12] C.R. Costea, H. Silaghi, D. Zmaranda, M.A. Silaghi, Control Systems Architecture for a Cement Mill based on Fuzzy Logic, International Journal of Computers Communications and Control, ISSN 1841-9836, Vol.10, No 2, 2015 